\title{
AN ANALYSIS OF TABOO WORDS AND EUPHEMISMS FOUND IN THE CHARACTERS' UTTERANCES IN THE MOVIE ENTITLED “THE PURGE: ELECTION YEAR"
}

\author{
Mangantar Sitohang1 \\ mangantar@stibaiecjakarta.ac.id \\ Sekolah Tinggi Bahasa Asing- IEC Jakarta \\ Sifa Cahayati \\ sifa@gmail.com \\ Sekolah Tinggi Bahasa Asing- IEC Jakarta \\ Mohamad Mansur \\ mansur@stibaiec-jakarta.ac.id \\ Sekolah Tinggi Bahasa Asing- IEC Jakarta
}

Sitohang, M., Cahayati, S. and Mansur, M. (2021). An Analysis of Taboo Words and Euphemisms Found in the Characters' Utterances in The Movie Entitled "The Purge: Election Year". Journal of English Language and literature, 6(2), 115-134. doi: 10.37110/jell.v6i2.129

Received: 09-06-2021

Accepted: 10-08-2021

Published:03-09-2021

Abstract : The aims of this research are to find and to discuss the types, functions of Taboo words and the types of Euphemisms. The qualitative method is used in this research since the description regarding the utterances found in the movie is necessary. The quantitative approach is used in this research as well in representing the data findings by using percentages. The research data are taken from the movie scripts and are formed from the characters' utterances either words or phrases. As the results, the researcher found five types of language of Taboo in the movie that consist of (1) Obscenity, (2) Epithets, (3) Profanity, (4) Insults and Slurs (5) and Vulgarity. Obscenity is the highest number of occurrence while Vulgarity holds the smallest number. There are four functions of Taboo language which are namely; (1) To draw Attention to one self, (2) To be Aggressive or Provocative, (3) To show Contempt, and (4) To mock Authority. To draw attention to one self is the most appeared functions of Taboo while to mock authority is the smallest number. There are four types of Euphemisms found in the movie which are (1) Euphemisms for Death and Killing, (2) Euphemism for Political Correctness, (3) Euphemisms for Sexual Activities, and (4) Euphemism for Addressing. The most appeared type of Euphemism is Euphemisms for Death and Killing while the least appeared one is Euphemism for Addressing.

Keywords: Taboo words, Euphemisms, The Purge: Election Year movie.

\section{INTRODUCTION}

Language is the most important element in communication. People who live in society need to communicate and language is the one that connects them. As living in the society's scope, people should be concerned about how they communicate with others by obeying the present communication ethics in that society.

People use language for any various purposes especially in expressing their minds including their

1 Corresponding Author 
emotions. According to Foolen (2012), language and emotions have a connection, and the connection between them is created when certain emotions are expressed verbally or in other words by using a language. This view is supported by Jay (2009) who writes that when most people use the language to express their uncontrollable emotions like surprise, joy, anger, or frustation, they will directly do swearing. Jay and Janschewitz (2008) stated that swearing which is used to express the speakers' emotions is included in the use of taboo language.

A conversation is basically formed in formal or informal (casual) one. According to Jay (2009), casual conversation is another use of taboo language with no intentions to be offensive but still be considered to be impolite. Recently, taboo language is very easy to be heard in society. People say it in various ways and with various purposes such as shouting it at someone to express their waves of anger, using it for jokes (in purpose to make a humorous atmosphere), and addressing other people by using the bad calls.

Eventhough language of taboo is recognized as the non-standard language and signifies as the language of under-educated people or lower class people, it does not guarantee that educated and upper class people do not use language of taboo as well. Almost all people from any background have tendencies to use language of taboo since there are reasons encouraging them to use it. Based on that condition, since there are possibilities that every one can use the language of taboo, no matter who they are, it becomes the writer's interest in writing this research in order to know the background or the reasons why the language of taboo becomes used.

Kusumaningsih (2019) sees that the use of taboo language is prohibited in society since it is improper with any religions and customs and the use of it also signifies the social culture, the educational background, and the identity of the speakers. Based on that condition, Allan and Burridge (2006) stated that in preventing the bad stereotype, people realize to censor their language to achieve well-being over themselves and others. In short, since the use of taboo language brings the negative stereotypes towards the speakers, people are also now aware to refine their language become inoffensive and more polite or indirect.

In censoring the language, people choose euphemisms to soften, to refine the language as well as to replace unpleasant words or the use of taboo language without changing the meanings and the messages. According to Wardaugh (2006), Euphemisms enable people to talk about unpleasant topics without being heard as taboo as the language itself gets disguised and neutralized. Since people have their own consideration in censoring their language in naming something unpleasant, thus it becomes the writer's interest to analyze what kind of euphemisms that commonly people use to address something unpleasant to be heard more acceptable towerds others.

Since the purpose of this research is to provide the information related with the use of taboo language and euphemisms that is expected can help the readers to avoid the misuse of taboo words as well as to know how to use the refined words in communication to be heard inoffensive towards the others. Following and supporting the purpose, the aim of this research is to analyze taboo words and euphemisms that are spoken by native English speakers.

The researcher uses a movie as one of the mass media which is a great source where taboo words can be found to be uttered by native English speakers. The researcher chooses the movie entitled The Purge: Election Year because this movie shows the habits of using taboo words in America which are supported with the actions that are also considered to be Taboo, such as committing crimes and killing people. The other reason is that instead of showing taboo words, this movie also shows some utterances of euphemisms that are spoken by the characters in the movie. 
There are previous researches that have been conducted with similar topics as this research. The first previous research that still has a relation with this research is conducted by Rahmayani and Fitrawati (2018). The aim of their research is to analyze the types and the function of taboo words that are uttered by the characters in the movie entitled The Wolf of Wall Street. The second previous research is conducted by Mózo (2017). The objective of her research is to analyze the semantic and structural features of the political euphemisms that are used in the English newspapers.

The difference that is found from both previous researches comparing with this research is that each of those researches does not conduct the analysis collaboration between both taboo language and euphemisms to become as one research. Moreover, since English language always gets developed, some new terms are also born following language development. Thus, the findings of this research contain some new terms of taboo and euphemisms that have not been found and discussed in those two previous researches. The objectives of the research are aimed as follows: (1) to identify and to describe the types and the function of taboo words used by the characters in The Purge: Election Year movie and (2) to identify and to describe the types of euphemisms used by the characters in The Purge: Election Year movie.

\section{LITERATURE REVIEW}

\section{Utterance}

According to Kreidler (2013), an utterance is speech or writing actions that are marked as the specific event which happens at a certain time and takes a certain place encompassing one or more persons who produce the utterance. Even though utterances only appear once, but those can be long-lasting if a spoken utterance gets recorded and if the others are represented in writing. This view is supported by Traum \& Heeman (1997) saying that the term utterance simply means "an act of speech". Similarly, according to Carter \& McCarthy (cited in
Nordquist, 2019) states that an utterance refers to complete communication units which involve single words, phrases, or clauses.

\section{Function of Speech}

\section{Function of Speech}

Kennedy \& Lubiner found that there are several ways of categorizing the function of speech:

a. Expressive utterances express the speaker's feelings, e.g. I'm feeling great today.

b. Directive utterances attempt to get someone to do something, e.g. Clear the table.

c. Referential utterances provide information, e.g. At the third stroke it will be three o'clock precisely.

d. Metalinguistic utterances comment on language itself, e.g. 'Hegemony' is not a common word.

e. Poetic utterances focus on aesthetic features of language, e.g. a poem, an ear-catching motto, a rhyme, Peter Piper picked a peck of pickled peppers.

f. Phatic utterances express solidarity and empathy with others, e.g. $\mathrm{Hi}$, how are you, lovely day isn't it!. (Kennedy \& Lubiner, 1993, p. 275)

\section{Taboo}

Radcliffe Brown (cited in Allan \& Burridge, 2006) defines the word 'Taboo' is primarily derived and developed from its original term 'Tabu' which means in the Polynesian language is 'to forbid', 'forbidden' which is extended to any kind forbidden acts. Similarly, Wardaugh (2006) defines the term taboo as any behaviors that are perceived to be prohibition or avoidance of culture in society which is deemed harmful to its members by causing them to be anxious, embarrassed, or shamed. This view is 
supported by Allan \& Burridge (2006) who hold the view that taboo is a prohibition of behaviors affecting everyday life and resulting from social restrictions on the behaviors of the individual in the event that it may trigger discomfort, harm, or injury.

The concept of the term 'Taboo' is divided into two aspects which are behaviors (non-verbally) and utterances (verbally), and those aspects are prohibited from being performed, expressed, and uttered in society. One of the effects of doing any taboo behaviors or speaking any taboo words is harming other people who are targeted to receive those prohibited behaviors and utterances. The other effect is getting the bad stereotype for having done any Taboo acts or having uttered any taboo words.

\section{The Types of Taboo Words}

According to Battistella (2005) and Jay (1992), Taboo Words are divided into some categories. Those categories are Epithets, Profanity, Vulgarity, Obscenity, Insult and Slurs.

\section{a. Epithets}

According to Jay (1992), epithets are short powerful outbursts of emotional language even more offensive than other forms of cursing. The epithet is spoken out of frustration which may also reflect a feeling of hostility. Furthermore, epithets can also be common in existence which can be seen as someone always repeats the same outbursts as they unconsciously hurt themselves. The brief and loud outbursts are shit, damn, hell, son of a bitch, goddamn it, up yours, fuck you, fuck off, piss off, Jesus Christ.

In addition, Hoeksema (2019) states that brief exclamations like Bullocks! Bullshit! Poppycock! are used to show frustrations and outbursts of disagreement in opinion between the speaker and the interlocutor in a very disrespectful way.

\section{b. Insults and Slurs}

Insults and slurs are also included as an important component of the language of Taboo: Insults and slurs are verbal attacks that are spoken to harm the other person by the word alone. Slurs may be racial, ethnic or social in nature and may indicate the stereotyping or prejudice of the speaker. Insults may denote the physical, mental, or psychological qualities of the target. Some insults use animal imagery: bitch, son of a bitch, jackass. Some are based on social deviations: slut, bastard, homo, queer. Children's insults are commonly based on physical (fatty, four eyes), psychological (dumb, weirdo), or social characteristics (liar, tattle tale). Ethnic and racial slurs: nigger, honkey, dago.(Jay, 1992, p. 8)

According to Allan and Burridge (2006, p. 82) "There are many imprecations invoking mental subnormality or derangement: ... Silly!, Retard!, Moron!, Idiot!, Fool!, Stupid!, Halfwit!, Nitwit!, Dickhead!, Fuckwit!, Fuckhead!, Shithead!. All these insults reflect the stigma attached to mental subnormality, which requires euphemisms for the genuinely subnormal."

In addition, Allan and Burridge found the following: Terms of insult include the following of comparisons of people with animals that are conventionally ascribed certain behaviors, for example, calling someone a bat, cat, fox, vixen, sow, pig, cow, bitch, cur, dog, mongrel, swine, louse, dove, hawk, coot, galah, chicken, turkey, mouse, rabbit, bull, ox, goat, ape, monkey, ass/donkey, mule, rat, snake, etc. (Allan \& Burridge, 2006, p. 79)

\section{c. Profanity}

Battistella (2005) defines profanity is a religious curse which varies from a gentle hell or damn to a more powerful goddamn involving the crude use of what is considered sacred.

Furthermore, Jay found the following: Profanity is based on a religious distinction. An example of profanity would be a word or phrase which seeks not to denigrate God, religion or holy affairs but would be based more on ignorance of or indifference to these matters. These might be something like: "Jesus $H$. 
Journal of English Language and literature

Volume 6, Issue 2, September 2021

Christ, I'm hungry!", "For the love of Christ, get off the phone!". (Jay, 1992, p. 3)

\section{d. Vulgarity}

Jay found the definition of the term 'Vulgarity' as explained in the following: Vulgarity means the language of the common person, "the person in the street", or the unsophisticated, unsocialized, or under-educated. To be vulgar is to be common, not necessarily bad or evil, they just reflect the crudeness of stress language. These words may be considered vulgar: snot, bloody, up yours, booger, slut, piss, crap, kiss myass, snatch, on the rag, puke. Moreover, he stated that vulgarity terms involve body parts, processes, and products. In addition, the body part name-calling utterances are Tits, Prick, Cunt, Cock, Dink, Dick, Dork, Pussy, Boobs. (Jay, 1992, p. 6)

According to Carpenter (cited in Mercury, 1995), vulgar language represents coarse, raw, and off-streets expressions which are also used to debase or devalue the thing or person to whom it refers to. "I have to take a crap and Wow, look at her tits!" are only two unique yet vulgar utterances which may be viewed as disrespectful, distasteful and offensive in certain contexts.

\section{e. Obscenity}

According to Jay (1992), labeling a word as obscene implies that it should not be used freely; it is subject to limitations, and it indicates the possibility of being sanctioned by the courts. Obscenities are sexual in nature in American English that are not publicly proclaimed and rarely to be used or found in public media. Words that would be restricted to the public would be fuck, motherfucker, cocksucker, cunt, or tits.

In Addition, Battistella (2005) states that "obscenity refers to words or expressions which characterize sex-differentiating anatomy or sexual and excretory function in a crude way, such as shit and fuck."

\section{The Function of Taboo Words}

p-ISSN 2540-8216, e-ISSN 2654-3745

https://journal.stibaiec-jakarta/ojs/index.php/jell

Taboo words are divided into four main function according to Wardaugh (2006) "linguistic taboos are violated on occasion to draw attention to one self, or to show contempt, or to be aggressive or provocative, or to mock authority."

\section{a. To draw attention to one self}

According to McGuire (1973), attention is generated through the use of the language of shock which is typically powerful, and enthusiastic with its connotations arouse the listener's immediate emotional reaction to that outrage.

For Krizan et al (2008), attention is drawn through a powerful message that removes unnecessary words as well as involves power words to construct a mental image.

\section{b. To show contempt}

According to Group, n.d. (Group, n.d.), contempt is the feeling of dislike for and superiority (usually morally) over another person, group of people, and/or their actions. It's widely believed that the function of contempt is to signal a feeling of superiority, of not needing to accommodate or engage, and to assert the power of status.

\section{c. To be aggressive or provocative}

According to Bostrom (cited in Fitzgerald, 2007), one of the offensive language's aims is to provoke people into violent confrontations and actions. The cathartic purpose is served in the use of offensive language since it allows the speakers to reduce and to release their emotions, frustrations, and aggression verbally rather than physically.

Moreover, according to Montagu (Fitzgerald, 2007) states that swearing is the cultural verbal expression or a release of aggressiveness accompanied with frustration.

\section{d. To mock authority}


According to (McGuire, 1973) one of the uses of offensive language is to discredit the organizations and leadership in position. This indicates the contradictory towards the establishment. It is also used to convey a profound contempt towards norms of culture, an anti-authority protest, and even disrespect to the things sacred.

\section{Euphemism}

According to Allan \& Burridge (2006), euphemism is described as words or phrases which serve an alternative to unpleasant expressions that emerge through intentional or unintentional self-censoring. According to a definition provided by Fromkin et al (2003), euphemism is a word or phrase replacing the language of taboo or to prevent any terrifying or dispreferred topics. A further definition is given by Burridge (2012) who describes as a language of avoidance, euphemisms are created. People generally create them when they think about things that they prefer not to talk about. As its main function, euphemisms are the language of escape generated in response to taboos.

The definition of the word euphemism is the words that are used to refine the existence of Taboo words. The refining words known as euphemisms are used to avoid the impoliteness and offensiveness in order to disguise the unpleasantness in a conversation. The use of euphemisms seems to be indirect meaning in talking the unpleasant things.

1. The Types of Euphemisms

a. Euphemisms of profanity

In 2006, Allan \& Burridge published a book in which they described: Because it was blasphemous to name the god of the Jews and his cohorts, the name was written without vowels, $Y H V H$, but read out either as $H a$ Shem 'The Name' or as Adonai meaning 'Lord'- a euphemism that has carried over into Christianity, in both addressing and naming God and Jesus Christ. There is a euphemism for Adonai used outside of formal religious service by devout Jews, Adoshem from Ha shem; very devout Jews will write $G-d$ for God (as Christians used to do), just as they would write $Y a h$, an acronym for the first two letters, Yod and Heh. (Allan \& Burridge, 2006, p. 38)

b. Euphemisms for the body parts Allan \& Burridge describe euphemisms for body parts: The slippery meanings of certain human body part terms (a linguistic phenomenon known by some as 'genital flip-flop'): the slang anatomical expressions fanny, prat and tail have all at some stage in their history meant 'buttocks' and 'female pudendum' - and in the case of tail, the 'penis' as well. Such was the trepidation in the Victorian era surrounding the part of the body between the diaphragm and the groin that the word belly was metamorphosed linguistically into stomach, chest and even viscera. (Allan \& Burridge, 2006, p. 183)

c. Euphemisms for sexual activities According to Allan \& Burridge: There are euphemisms terms for activities that are considered to be sexual. One of the sexual activities is 'oral sex' with the euphemisms for that is the word eat, and this is also used occasionally in English for both copulation and oral sex. Certainly, the talk between lovers is sometimes strikingly cannibalistic I could eat you up; I want to suck you dry. (Allan \& Burridge, 2006, p. 151)

In addition, Burridge (2012) stated that the phrase to sleep with is the euphemism for the literal meaning of "have sexual intercourse" which has been used since the $10^{\text {th }}$ century. The phrase doing it is also an euphemism which is formed as the replacement of the literal meaning of "sexual intercourse". 
d. Euphemisms for death and killing

According to Allan and Burridge (2006), any terms related to the death of someone would preferably be refined using euphemisms as it is an undesired topic to be talked about. The word sleep is one of the Euphemisms for death which indicates the absence of soul of any living creatures. In addition, death is frequently refined euphemistically as a journey for the dead person's soul to a better place and the euphemisms for that include part, depart, pass, pass away, pass on, pass over, and arrival at the final resting place and reunited with loved ones.

Allan \& Burridge (2006) describe that all legally sanctioned killings are initiated with euphemisms. The word executions, for example, are euphemisms for any legal killings, and the word is formed from the phrase 'to execute' which means 'to do perform'. Other examples of euphemisms for killing are used by militarese which are functioned to point of deception, such as pacify which means 'be killing (be at war with)'; neutralize and salvage which means 'kill selected targets'.

e. Euphemisms for addressing people particularization

According to Cruse (2006), addressing is the use of euphemisms to designate the addressee by using specific pronouns that are chosen based on the relationship between the speaker and the addressee and also based on the situation.

In addition, According to Warren (1992), addressing people is performed by replacing its general word from the dictionary with the refined contextual word and that is known as the term of particularization which in use to make general words to be particularized contextually.

f. Euphemisms for political correctness According to Allan \& Burridge (2006), euphemisms for political correctness use the courtesy for not being offensive in naming others and the aim is to eliminate the stigma of negative social stereotypes. As political correctness is used in political fields, it will definitely draw more attention than other linguistic censorings, seek to enforce, and social change.

\section{METHOD}

This research uses a qualitative research method since the data that is shown or represented in the word form of the utterances rather than the numerical data forms. Specifically, the type of qualitative method that is used in this research is the content analysis which is defined by DowneWambolt (cited in Bengtsson, 2016, p. 9) as "a method that provides a systematic and objective means to make valid inferences from verbal, visual, or written data in order to describe and quantify specific phenomena." This kind of research method is applied because the description of utterances of the taboo and euphemistic words is needed. The description and explanation regarding the related utterances are created based on the sources that provide the theories related to it. Even though this research uses the qualitative research method, the quantitative method is also used as the percentages are used to show the findings.

The data that is used in this research is document analysis which is defined by Bowen (2009) as a systematic procedure for reviewing as well as evaluating documents both in printed and electronic including books, journals, radio and television programs scripts, etc. 


\section{FINDINGS AND DISCUSSIONS}

\section{Findings}

In this section, the researcher shows the data findings related to the types of taboo words, the types of taboo words as well as the types of euphemisms. From the total data showed in the appendix 1, 2, and 3, taboo words as well as euphemisms found in the movie that is classified based on the types and its functions are summarized into numbers and percentages as displayed in these three following Tables (Table 1., Table 2, Table 3.).

Table 1. The Types of Taboo Words in the Movie Entitled The Purge: Election Year

\begin{tabular}{cccc}
\hline No & Types of Taboo Words & $\begin{array}{c}\text { Total of Taboo } \\
\text { words uttered }\end{array}$ & Percentage \\
\hline $\mathbf{1}$ & Obscenity & 44 & $28.03 \%$ \\
\hline $\mathbf{2}$ & Epithets & 34 & $21.66 \%$ \\
\hline $\mathbf{3}$ & Profanity & 32 & $20.38 \%$ \\
\hline $\mathbf{4}$ & Insults and Slurs & 27 & $17.20 \%$ \\
\hline $\mathbf{5}$ & Vulgarity & 20 & $12.74 \%$ \\
\hline & Total & $\mathbf{1 5 7}$ & $\mathbf{1 0 0 \%}$ \\
\hline
\end{tabular}

The types of taboo that are found from the movie are divided into five types, these types are obscenity, epithets, profanity, insults and slurs, and vulgarity. From the table above, it shows that one of the types of taboo that is uttered the most by the actors is obscenity which in total is 44 taboo words that are spoken with the number of percentage is $28.03 \%$. The second type of taboo is epithets which shows the total number of the taboo word expressions frequency is 34 with the percentage number is $21.66 \%$. The third position as the most spoken taboo words is profanity which shows 32 taboo words of each as well as the percentage number which is $20.38 \%$. The fourth type of taboo words is insults and slurs with the total of taboo words spoken is 27 and the percentage is $17.20 \%$. The last type of taboo words is vulgarity which carries 20 words that are found in the movie with the percentage is $12.74 \%$.

Table 2. The Functions of Taboo Words in the Movie Entitled The Purge: Election Year

\begin{tabular}{ccll}
\hline No & Function of Taboo & $\begin{array}{c}\text { Total of Taboo } \\
\text { words uttered }\end{array}$ & Percentage \\
\hline $\mathbf{1}$ & To draw Attention to one self & 114 & $72.61 \%$ \\
\hline $\mathbf{2}$ & To be Aggressive or Provocative & 21 & $13.38 \%$ \\
\hline $\mathbf{3}$ & To show Contempt & 17 & $10.83 \%$ \\
$\mathbf{4}$ & To mock Authority & 5 & $3.18 \%$ \\
\hline & Total & $\mathbf{1 5 7}$ & $\mathbf{1 9 9 \%}$ \\
\hline
\end{tabular}


The functions of taboo that are found from the movie are divided into four, these four are: To draw attention to one self, to show contempt, to be aggressive or provocative, and to mock authority. From the table above, it shows that one of the function of taboo that is the most frequently uttered the most is to draw attention to oneself which has the number of taboo words is 114 as the number of percentage appears
$72.61 \%$. The second function of taboo is to be aggressive or provocative and it owns 21 taboo utterances and it has the number of percentage which is $13.38 \%$. The third function is to show contempt that has 17 taboo words in total with the percentage is $10.83 \%$. The last function of taboo is to mock authority which carries 5 words that appear in the movie with the percentage is $3.18 \%$.

Table 3. The Types of Euphemisms found in the Movie Entitled The Purge: Election Year

\begin{tabular}{clcc}
\hline No & Types of Euphemisms & $\begin{array}{c}\text { Total of Euphemistic } \\
\text { words uttered }\end{array}$ & Percentage \\
\hline $\mathbf{1}$ & Euphemisms for Death and Killing & 105 & $93.75 \%$ \\
\hline $\mathbf{2}$ & Euphemisms for Political Correctness & 3 & $2.68 \%$ \\
\hline $\mathbf{3}$ & Euphemisms for Sexual Activities & 3 & $2.68 \%$ \\
\hline $\mathbf{4}$ & Euphemisms for Addressing & 1 & $0.89 \%$ \\
\hline & Total & $\mathbf{1 1 2}$ & $\mathbf{1 0 0 \%}$ \\
\hline
\end{tabular}

The total of the euphemisms that are found in the movie is 112 . The types of euphemisms that are found from the movie are divided into four, they are euphemisms for death and killing, euphemisms for political correctness, euphemisms for sexual activities, and euphemisms for addressing. The type of euphemisms that is the most frequently used the most is to euphemisms for death and killing which has the number of euphemistic words is 105 as the number of percentage shows $93.75 \%$. The second types that have the same number of frequency are euphemisms for political correctness and euphemisms for sexual activities that have the number of euphemistic words is 3 of each and the same number of percentage which is $2.68 \%$. The least frequency is carried from one of the types of euphemisms which is euphemisms for addressing that is only uttered once with the percentage is $0.89 \%$.

\section{Discussions}

In this section, the Findings data that have been displayed in the previous section will be discussed more detail to provide the answer for the problem formulations. The complete findings in the appendix will be taken using stratified random sampling to represent each of the problem formulation. Thus, this section will cover each part such as the types of taboo, the functions of taboo, and the types of euphemisms.

\section{Types of Taboo Words}

\section{a. Obscenity}

Obscenity is found to be the most highly continually uttered by the actors in the movie. The words that are identified as obscenity found in the movie are fuck, motherfucker/motherfucking, shit, cocksucking/cocksucker, mofo. The word fuck contributes the highest number in the movie which occurs 26 times as the obscene word. One of the examples of the use of the word fuck found in the actor's utterance in the movie can be seen in the following utterance: 
Senator Charlie: "You cannot do this. Ineed to win this thing fair and

fucking square."

The dialogue above happens when Senator Charlie that is getting settled in the triage service center of the anti-NFFA community suddenly overhears the chaos. She soon enters the restricted room on purpose and figures the shocking things out in that room. She realizes that the anti-NFFA is now planning to assassinate Minister Edwidge Owens and other NFFA people. Senator Charlie strictly against what the anti-NFFA has planned so far because she thinks that if they ever killed the Minister, the Minister would be martyr, and Senator Charlie would automatically lose her Presidency opportunity.

In the dialogue above, Senator Charlie tells Angel and other anti-NFFA people should stop the Purge plan on the Minister because she has to win with the fair and honest ways. The utterance above shows a taboo word which is the word 'fucking' that is categorized as obscenity. In a study conducted by Candra \& Megandari (2018) showing that the word 'fucking' is recognized obscenity because it represents sexual activities. In addition, the particular sexual activities that are carried from the word 'fucking' is specialized to have sexual intercourse. This word is considered very offensive to be directed to other listeners or interlocutors to show hostility or rage. Similarly, Farisi et al. (2017) found that the word fuck literally means to have sexual activity that leads to a sense of disgust and becomes forbidden to be used in public media.

However, the word 'fucking' above is uttered not to show any sexual activities, but according to Mattiello (cited in Anglick et al., 2019, p. 3) the word 'fucking' itself in that context is considered as expletive infixation. Mattiello (cited in Anglick et al., 2019, p. 3) defines "expletive infixation (also called fuckin-infixation, from the most common infix used) concerns the insertation of expressive (often vulgar or obscene) expletives into words."

Thus, the speaker in the movie uses the word 'fucking' actually is intended to express her emotions regarding her unwillingness towards the interlocutor by emphasizing her utterance. The contextual meaning of the word 'fucking' in the dialogue above is pointed to the following word which is 'square' which means honest. She emphasizes the word honest by using the word 'fucking' wanting Angel to understand what she really means and will stop their Purge plan on the Minister. By that condition, her utterance above is identified as expressive in terms of the function of speech.

\section{b. Epithets}

Epithets come as the second of the most uttered type of taboo words after obscenity in the movie. The examples of epithets words found in the movie are hell, motherfucker/motherfucking, bitch, damn, son of a bitch, bullshit, goddamn, holy shit, screwed/screwing, horseshit. One of the epithet words that can be seen in the following utterance is going to be explained in more detail:

\section{Senator Charlie: "No. No bullshit. I want a real answer."}

One of the examples of epithets that is going to elaborate comes from the word 'bullshit' which appears 4 times in the movie. The literal meaning of the word 'bullshit' is the feces of the bull. However, Miller (2015) points out that the word 'bullshit' itself connotatively is defined as a language that does not suit the actual states of affairs instead of the speaker's motives.

The dialogue above occurs when Senator Charlie asks Leo Barnes personally a question about the reasons he applied that job to protect the Senator. As Senator Charlie hears Leo's answer saying that the only reason he applied for that job because he likes the Senator's politics, Senator Charlie suddenly cuts Leo's sayings because she thinks his reasons totally lie. According to Hafiza et al. (2020), the word 'bullshit' in the utterance above is uttered to show disagreement and disbelief of the speaker towards their interlocutor whose statements are considered to be untrue or lies. The word 'bullshit' is triggered from Senator Charlie's disbelief in order to against Leo's dishonest answer. 
Journal of English Language and literature

Volume 6, Issue 2, September 2021

The disagreement and disbelief above are expressed with a short and loud burst that is considered as the exclamations. It becomes taboo since the speaker of the word 'bullshit' directly shouts impolitely at their interlocutors who are considered having spoken lies and this way will definitely humiliate them and show that they are liars. Based on the conditions explained, the utterance above indicates the function of speech which is expressive since the speaker shows her feelings of disbelief and disagreement.

\section{c. Profanity}

The taboo words found in the movie that are included in profanity are hell, god, damn, Jesus, goddamn, son of god, lord. These 6 different taboo words are indicated to be profanity because the speaker uses the religious terms based on the ignorance of the religious purposes or the religious devotion and not intending to disparage God or any religious matters. The religious terms are believed to be used only in the particular sacred places like in the church as well as it is used in the religious activities like in preaching the sermon. On the other hand, if any of the religious terms are used out of religious purposes or if the name of God is uttered in vain, then the utterances will be considered as taboo. The example of profanity word found in the movie is shown in the utterance as follows:

\section{Joe Dixon: "God, I hate that she's out there like} that."

The utterance above happens when Laney passes by in front of Joey's Deli after she has just dropped a purge victim off at the triage service center. She immediately gets out from the van to greet Joey and his employee, Marco who are sitting together on the rooftop protecting the Deli from the purgers. Laney tells these two men that she has just helped a man who got shot by his wife. Laney also tells about how the wife firstly approached Laney's van on the street hysterically screamed asking for help after she had just shot her husband on purpose. Hearing Laney's story, Joey seems somewhat worried about her condition having so many risks helping the Purge victims during this dangerous
p-ISSN 2540-8216, e-ISSN 2654-3745

https://journal.stibaiec-jakarta/ojs/index.php/jell

night. After Laney gets in the van and heading to continue her mission, Joey says the statement as shown in the line script above.

The word 'God' in the utterance above that is categorized as profanity appears 9 times in the movie. Gao (2013) points out that the word 'God' containing the word of taboo since the names of God is too sacred to be treated equally like other common words. Likewise, Mocanu (2017) holds the view that the names given to God are considered to be taboo since the speaker calls the names of God in vain. The view about calling God in vain is taboo is actually proven when the word 'God' is uttered by people does not show any religious devotions as well as does not show a sign of speakers' worship to God.

The meaning of the word 'God' here is the same both in literal and contextual which are the creator of the universe as well as the creator of the living and non-living creatures inside the universe. Joe utters the word 'God' merely to show that he is apprehensive about Laney being outside during this deadly situation that threatens her life. His utterance tends to be secular (being worldly) and it is not attempted to any religious matters. In addition, the utterance above seen from the side of the function of speech is phatic because Joey is empathy for Laney, or in other words, he really understands about the condition and the situation that Laney is dealing with at that time.

\section{d. Insults and Slurs}

The words in the movie that are indicated to be included in insults and slurs are the words bitch, son of a bitch, pig, stupid, old fuck, nasty, nosey old dog, coward, idiot, lunatic, big dope, white folks, white people, rat, chicken, crazy/the crazies. These 16 different taboo words are categorized to be insults and slurs because they are used to harm the listeners directly by addressing them with very offensive calls. These offensive calls reflect either the real listeners' characteristics or the visual imagery for the characteristics of the listeners that are made up by the speaker in order to insult and to humiliate them. One of the insults and slurs word 
that is found in the movie can be seen in the following utterance:

\section{Leader Caleb Warrens: "I have had it with all these idealistic pigs."}

The dialogue above takes place in the official NFFA meeting that is attended by the NFFA members of the party. They are discussing the strategy to get rid of the Presidential Candidate known as Senator Charlie as well as they want to eliminate the anti-NFFA people that is led by Dante Bishop. The reason they want to get rid of Senator Charlie because she explicitly declares to end the Purge. The leader of NFFA, Caleb Warrens does not want anyone can ever dismantle the Purge that has been officially included in the U.S. Constitution for almost 25 years. While performing the Purge, many protests come from the disadvantaged people who become the targets of the Purge against this inhuman regulation. Considering it would be the biggest threat for the NFFA, they decide to get rid of the NFFA detractors who put the biggest influence to make the NFFA come to an end and they are Senator Charlie and Dante Bishop.

The word 'pig' appears 3 times in the movie and it is considered as insults instead of slurs. Leader Caleb Warrens uses the word 'idealistic pigs' to point to those two NFFA detractors. According to Ruiz (2015) the names of animals that are used to address humans are to insult as well as to offend others. Fadaee (2011) holds the view that the word 'pigs' is used to represent the human's characteristics that are recognized as someone who is greedy in satisfying their lusts.

Leader Caleb Warrens uses the word 'pigs' to symbolize those 2 people's characteristics are just the same with pigs'. This word is very hurtful since no one in this world wants to be called or compared with animals. The adjective word 'idealistic' here is said describing that those 2 people have the same idealistic and humanism goal for everyone's rights to end the Purge. Their idealistic goal is the reason why Leader Warrens really hates them because of their mission. From the Leader Warrens' statement above is known that he has already fed-up with those people's interference and he really wants to ruin their mission. Moreover, the utterance above is classified as expressive in terms of the function of speech since his speech is intended to express his feeling that contains anger and humiliates others.

\section{e. Vulgarity}

Taboo words found in the movie that are known as vulgarity are the words: ass, pussy, asshole, cunt, smartass, badass, balls, crap, titties. Those words identify the body parts, the body process, and the body products. Vulgarity utterances reflect the language of common people and denote as undereducated and unsophisticated language while upperclass people tend to use the standard language rather than the common language (vulgarity). This circumstance gives the stereotype to the speaker of vulgarity as well as it differs from the standard language that is mostly spoken by the upper-classes. The further explanation about the use of vulgarity is presented through the example of one of the vulgarity utterances found in the movie as shown in the following utterance:

\section{Dante Bishop: "Bring your asses down here."}

The dialogue above happens in the church when Leo, Marcos, Joe, and Laney get a gunshot counterattack from the NFFA paramilitary force after those four brave people have shot the NFFA people in the church in order to help Senator Charlie. Because they have very less amount of people either to defend or to strike back to the NFFA paramilitary force, they suddenly get down hiding from the gunshots behind the church pews. After the gunshots suddenly disappear, they slowly stand up from their hiding place and soon realize that the anti-NFFA people have come to help them by having shot all the paramilitary force.

Dante Bishop, the leader of anti-NFFA shouts from the altar to those four people who are still standing behind the pews on the stairs to come down. He utters the word 'asses' to denote those four people's physical bodies. According to Kusumaningsih (2019), the word ass itself in literal meaning is another word for bottom, buttocks, anus 
Journal of English Language and literature

Volume 6, Issue 2, September 2021

which are used in certain social classes and ethnic groups. Moreover, Holgate et al. (2020) state that the word ass is a vulgar word that is functioned to abuse others, to emphasize feelings, and to show emotions.

The word ass is a part of the human body as well as it represents the human's full body. Thus, if someone ever asks the other to move their asses, it means they need to move their whole bodies (since ass here is a representation/replacement word for the whole body itself or the referred person). Dante says the word 'asses' instead of ass because he points to more than one person, so the word ass gets pluralized becomes 'asses'. Here in his statement is classified as Directive utterance because he directs them to follow his instruction to get down since the word 'asses' itself represents their whole body.

\section{Function of Taboo Words}

a. To draw attention to oneself

Taboo utterances found in the movie that are indicated as the function of Taboo word which is to draw attention to oneself are used by the speakers to make someone notice them or to alert attention to the speakers. Immediate attention is drawn by using the powerful as well as the strong words and that how taboo words work for. The example of taboo utterance that functions to draw people's attention is shown through the following utterance:

Rondo: "Seriously, Laney, who the hell are these people?"

The dialogue above is spoken by Rondo, an injured victim of the Purge night. Laney gives him help and rides him to the triage service center with himself gets handcuffed because Laney does not want to let him do the Purge revenge on his rival gang. He has got the first aid from Laney for his serious bullet wounds before Leo, Senator Charlie, Joe, and Marcos finally also get in the Triage van joining Rondo and Laney to go to the same place, the triage service center. On their way to the destination, Senator Charlie opens a conversation with each person in the van. Rondo has been lying on the stretcher hearing their conversation without
p-ISSN 2540-8216, e-ISSN 2654-3745

https://journal.stibaiec-jakarta/ojs/index.php/jell

knowing each of them except Laney the one who he knows really well. Feeling strange with people that talking and joining their ride, Rondo starts to distract their conversation with a really quick question asking about who these people really are.

In literal meaning, the word 'hell' is a place where the punishment is given after death to every human for their sins. Rondo utters the word 'hell' to grab Laney's attention to stop her conversation with others and answer Rondo's curiosity after he has already asked the same question to Laney before. According to Rahmayani \& Fitrawati (2018), this Taboo word that is uttered has a strong connotation as its function is to gain others' attention. Rondo's utterance is considered as Expressive since the speaker is expressing his curiosity through the question that he is asking to Laney.

\section{b. To show contempt}

The second function of taboo that is found within the movie is to show contempt. This function performs to show the hatred towards someone else as well as to have an aversion to the actions of another person or a group of people. The disrespect over some people is shown straightforwardly. The profound explanation of the function of to show contempt is delivered as in represented in an utterance as follows:

Senator Charlie: "If the voters get wind that I'm hiding in a fortress like some rich asshole, I lose votes and the NFFA wins."

The dialogue above occurs when Senator Charlie and her people watch the news announcing that the government has revoked the rules protecting the official government in the Purge night. Knowing this shocking new regulation that threatens Senator's life, Leo quickly decides to plan to set a safe house to protect Senator in the Purge night. Nevertheless, Senator opposes Leo's plan to avoid the Purge night by hiding in the secured house. She thinks that his plan will thwart her Presidential election and she will lose her votes as well because of that. 
The word 'asshole' is another term that refers to the word anus in the literal meaning. In other words, the contextual meaning of the word 'asshole' here is denoted to the person who is stupid, annoying, or someone who does the stupid things. The Taboo word that she uses is targeted to the rich people who will do the same as what Leo's plan which is hiding in the secured house. In her view, she wants to be treated equally like everybody else who will struggle the same in the deadly night. She uses that Taboo word to satirize to the rich people who have the power to protect themselves not like the disadvantaged people who do not have the same power.

By the function of taboo language which is to show contempt is further explained by Telles et al. (2019) as it is done by insulting the addressee that they think is worthless and can not be respected. Senator Charlie shows the contempt towards the rich people and puts herself not wanting to be like one of them. Her utterance is denoted as expressive since the speaker is expressing her disagreement towards Leo and shows the aversion against the rich people.

\section{c. To be aggressive or provocative}

The third function of taboo language is to be aggressive or provocative. This function differs from each term which is to be aggressive or to be provocative. The difference between each of them will be explained in deep through the following utterance:

\section{Dante Bishop: "Shut the fuck up!"}

The dialogue that is spoken by Dante as shown above happens when he seizes Minister Edwidge Owens after Dante and other anti-NFFA people have succeeded to stop the Purge action that is attempted to Senator Charlie. Dante has planned to do the revenge on the Minister and brings the Minister to the room and he is about to shoot him in the head.

Dante is becoming hesitant to shoot him as he is considering what Senator Charlie has warned him not to kill the Minister because if that thing happens, the Minister will become the martyr and automatically it will defeat Senator in the election. While standing motionless pointing the gun at the Minister, the Minister starts driveling and shouting at Dante convincing Dante to kill him because it is Dante's right as an American in the Purge day.

What the Minister is doing to ask to be killed annoys Dante, soon he shouts at the Minister to stop talking by saying the statement in the utterance above. By uttering the word 'fuck', Dante expresses his anger towards the Minister. In other words, expressing anger also means delivering aggression towards someone and that is identified as one of the function of Taboo which is to be aggressive. This view is supported by Jdetawy (2019) saying that swearing is created as a reaction of annoyance, stress, and anger. This utterance is classified as directive that is shown with Dante exclaims asking the Minister to say no more.

Another function of taboo is to be provocative, and it will be discussed in more detail by analyzing the following utterance:

Joe Dixon: "You should be thanking my black ass for helping you instead of interrogating me."

The dialogue above indicates the function of taboo which is to be provocative. This function of taboo is aimed at provoking someone's anger or causing someone to confront the speaker. Overhearing Leo who keeps questioning Marcos about his identity, his country origin, and his reasons to come to America makes Joe is peeved about Leo who seems like interrogating Marcos. As Leo is finished with his curiosity about Marcos, he suddenly turns to Joe asking his name. Joe is suspicious of Leo who will interrogate the same way as he does to Marcos. Instead of telling his name to Leo, he warns Leo to stop asking too much to them. Joe even confidently provokes Leo to thank his 'black ass' for having helped Leo from the Purgers instead of asking Joe many questions. The word 'black' in the phrase of 'black ass' is put as an identifier to describe the color of the 'ass' itself since Joe describes himself as a black person. 
Journal of English Language and literature

Volume 6, Issue 2, September 2021

Joe successfully provokes Leo's anger as Leo soon confronts what Joe has said. Leo angrily says that Joe's feelings are none of Leo's business, so he does not mind to have made Joe feel offended. One of the function of taboo language based on that condition is to be provocative which is also explained in detail by Rahmayani \& Fitrawati (2018) as the speaker's intention in uttering taboo word is to provoke certain responses from others such as violation or anger. This kind of utterance above is considered to be directive since the speaker wants the interlocutor to do what the speaker wants.

\section{d. To mock authority}

The last function of taboo that is the least used in the movie is to mock authority. This function is used to show the disrespect towards the authorities and to dishonor the existing government officials or the institutions. The further explanation regarding this type of taboo is derived from this utterance as follows:

Laney Rucker: "Goddamn conniving, duplicitous, crooked, cocksucking politicians."

The utterance above is spoken by Laney when she previously wonders about Senator Charlie who is being chased by the NFFA. As Senator Charlie confirms to Laney's question that NFFA does put an attempt to seize Senator Charlie, Laney starts mocking the NFFA officials by saying those various Taboo words as shown in the utterance above. Laney thinks that what the NFFA does to Senator is totally savage as well as they do it to the other people. The inhuman regulation that NFFA has carried out so far is terribly sadistic and it brings Laney into her aggression that is shown towards the NFFA and their regulation as well.

The phrase 'Goddamn conniving' contextually means as the cunning politicians, and for its literal meaning the word 'goddamn' means that God punishes humans in the afterlife for their sins. The other Taboo word is the word 'cocksucking' in the phrase 'cocksucking politicians' which has a contextual meaning as deceitful politicians while
p-ISSN 2540-8216, e-ISSN 2654-3745

https://journal.stibaiec-jakarta/ojs/index.php/jell

the literal meaning of the word 'cocksucking' itself is sucking the penis.

According to Rahmayani \& Fitrawati (2018), people sometimes use the language of taboo to show their disappointment and disbelief towards the Government or institutions' performances. Laney Rucker strictly expresses her irreverence towards the NFFA officials by saying those offensive words in that is functioned to mock authority. In addition, her utterance is categorized as Expressive since it contains Laney's perspectives towards the NFFA.

\section{Types of Euphemisms}

\section{a. Euphemisms for death and killing}

Euphemisms for death and killing are the most used type of euphemisms in the movie. This type is used to refine the fear words of death as well as the killing. Death is one of the biggest fears that every human has. Thus, rather than explicitly saying the word of death itself, there are some euphemisms to soften the words to be heard. In addition, since killing is also a taboo action to be done, so the language needs to be censored when conveying about that sensitive topic. Unlike the illegal killings, for the legal killings (one that is sentenced to the capital punishment) already have the terms of killing itself. In this movie, there are some variations of words are said that reflect the Euphemisms for killing such as purge/purging, purify, eliminate/eliminating, purgers, assassinate, assassination, assassin, execution, spring cleaning.

As in connection with the title of this movie that contains the word 'Purge', here is the example of the euphemistic word 'Purge' that contextually means to kill is shown in the following utterance:

The Announcer: "This is your Emergency Broadcast System announcing the commencement of the annual Purge sanctioned by the U.S. government."

The word 'Purge' appears the most which are 83 times in total among the other Euphemistic words found in the movie. The utterance above is a part of the official announcement that announces if the Purge that is held every year will be soon 
commenced at the siren. According to Holder (2008, p. 312) "the word 'Purge' means to attack violently which is another form of cleaning out." Price (cited in Holder, 2008) writes that the term 'Purge' was ever used by Israelis euphemistically in the phrase 'purging operation' which was denoted in performing the real purge on Fatah. Moreover, in the politicus (cited in Brock, 2000) mentioned that the actions of 'violent purges' consisting of killing and expelling individuals.

The word 'Purge' in the utterance above is denoted to get rid of people by legalizing the murder actions that can be done by anyone in America. American citizens even the tourists can target anyone to be killed in the Purge Night without worrying about the punishment they will get from killing people since they do it $\mathrm{n}$ the Purge Night. In short, the word 'Purge' is a given term from the U.S. government for the killing action in order to bring America as a reborn country (to be cleansed) and as long as the killing action that is carried out is legal, then the word that represents its action should be censored and that is why they use the word 'Purge' to disguise the direct literal meaning of killing. The utterance above indicates the function of speech which is referential because an announcement is functioned to announce, to spread, or to inform the certain, necessary, and urgent information to other people.

\section{b. Euphemisms for addressing people}

Another type of euphemisms found in the movie is for addressing People. There is only one word that is uttered in the movie in order to address people in the refined or inoffensive words and the word is 'white-haired'. This type of euphemisms is considered to be used depending on the relationship with the addressee as well as the situation when or where the conversation takes place.

Euphemisms are much way better to use in addressing people to show respect towards the addressee and the listeners as well. In other words, the speaker of this type of euphemisms will be marked out as a polite and respectful person. For the further explanation, here is the example of the euphemistic word that is uttered to replace the offensiveness in addressing the elderly as shown in the following utterance:

Joe Dixon: “... she be taking on them ol' white-

haired George Washington wannabe mofos all by herself."

Joe Dixon has doubts about the winning of Senator Charlie over the Election. Joe thinks that Senator Charlie is very brave to declare publicly about her resolution to cease the Purge and to revoke it from the constitution forever. On the other hand, Joe also thinks that the possibilities of Senator Charlie winning the election are very low comparing her rival, Minister Edwidge Owens.

Even though Joe's view believes that Senator Charlie can not win hands down, he thinks that Senator Charlie still can get the elderlies' votes. He thinks so perhaps because the elderlies are very concerned with the expiration of the Purge in America since their perspectives are more humanely about this country. The elderly seem that they want America to be a peaceful country as well as they want the violence comes to an end. In the utterance above, Joe uses the phrase 'white-haired' which is recognized as the euphemism for addressing people. The term white-haired is also used by Fradenburg \& Freccero (1995) to refer to people who are old age.

Instead of saying the word 'old people' directly, Joe softens his phrase by saying 'whitehaired' which is indirectly denote people who are old. In conclusion, the utterance above is recognized as expressive because Joe shows his view towards Senator Charlie believing she will get the votes from the elder even though she will not win easily.

\section{c. Euphemisms for political correctness}

The third type of euphemisms which is for political correctness is used in the movie scenes while both politician and non-politician have their turn to speak up in front of people. Almost all the people watch and pay attention to the speech or the sayings that are delivered by the influential people and the people who grant the power (the politicians), so the speakers have to always keep using the inoffensive 
Journal of English Language and literature

Volume 6, Issue 2, September 2021

words in their speech. In results, even though the speakers are conveying the real issues regarding certain people, the people who watch them will not get offended by the words uttered as long as the speaker uses the euphemisms. The speakers do not disguise the truth in their speech, but they do refine as well as censor the language while delivering the truth. To make it clear, here is the example of the euphemisms for political correctness that is found in the movies line script:

Senator Charlie: "More low-income people are killed during the Purge than anyone else."

In democratic presidential candidate debate, Senator Charlie confronts to her rival's inhuman resolutions saying he will continue to carry out the extent annual purge if he is elected as the next president. Senator Charlie is fed up hearing the minister Edwidge Owens' statements saying that the Purge is only the best way to save the country from the economic ruin, to help the people get rid of hatred, to decrease the number of crimes and he also believes that America has been built upon the sacrifice since the revolution and the world war II. Senator Charlie suddenly cuts his statement and saying the tragic facts that are made because of the existence of the Purge and one of those is shown in the dialog above. She says that many 'low-income' people are killed during the Purge.

The term 'low-income' here is defined by Rawson (1981) as the Euphemism form of the word poor. Instead of saying poor which sounds very offensive to certain referred people, Senator Charlie uses the word 'low-income' to refine the word poor in order to avoid offending and humiliating any persons. This condition is supported in the New Republic (cited in Rawson, 1981) explaining that the Census Bureau had officially replaced the term poverty became 'low-income' in the Census report publicity to be heard more acceptable and inoffensive.

Being professional is another reason to use that refined word in order to create a good figure since she works for politics and absolutely all people always pay attention to her. The utterance above is
p-ISSN 2540-8216, e-ISSN 2654-3745

https://journal.stibaiec-jakarta/ojs/index.php/jell

identified as referential because the speaker is revealing the fact to the people.

\section{d. Euphemisms for sexual activities}

Since sexual activities are taboo to be talked about, so the censored language is obviously needed in talking about this sensitive topic. There are several activities that are indicated to be sexual and one which is found in this movie is the term 'sexual intercourse' which refers to the sexual satisfaction that is done by doing penetration between couples. The Euphemistic phrase of the word 'sexual intercourse' is found to be spoken three times in this movie, and here is an example of the euphemistic utterance for the phrase 'sexual intercourse' that is shown in the following script line:

Joe Dixon: "All that useless shit and can't butter a damn bagel correctly."

Joe Dixon as well as Laney put no hope with the resolutions of Senator Charlie saying that she will put an end to the Purge. Joe even does not want to believe anyone's goals to stop the Purge forever in America because the efforts to dismantle the Purge have been just hopeless and useless since the NFFA has taken control over the country for 20 years so far. Hence, Joe doubts what Senator Charlie plans to end the Purge since her rival comes from the NFFA party which has the greatest power in the country. He says that her resolutions will go vain and Joe thinks that she even 'can't butter a bagel'.

'Butter a bagel' is the euphemisms for the phrase 'sexual intercourse'. The word 'bagel' itself is defined by Chris Lewis (cited in Dalzell \& Victor, 2006) symbolizing the female genital organ because the shapes between the bagel and the women's private part are nearly similar. Definithing (Butter the bagel, 2020) published on the internet related to the definition of the phrase 'butter a bagel' that is used to illustrate the process of ejaculating after having sex and spreading the sperms (symbolized as butter) all over vagina (symbolized as a bagel).

The phrase 'can't butter a bagel' is said by Joe because he underestimates that Senator Charlie can win the election on her own and so he thinks that 
she also absolutely can not have the sperms spread around her genital part correctly. He humiliates Senator Charlie saying indirectly that she can not have good sexual intercourse by changing and disguising the phrase of sexual intercourse itself into the food names (butter and bagel).

Using metaphor is one of the euphemisms' characteristics by replacing one offensive or sensitive word into similar but inoffensive ones. In this case, Food names are used to represent sexual activities to be heard indirectly. This utterance shows one of the functions of speech which is expressive that is indicated with the speaker's opinions towards the other person.

\section{CONCLUSIONS}

Taboo words uttered in the movie that are identified into various types and function are included in the main scope of the first objective of this research. The number of words that are indicated as taboo found in the movie is 157 in total. There are five types of taboo words which consist of obscenity, epithets, profanity, insults and slurs, and vulgarity. The highest rank of the frequency of the types of taboo words comes from obscenity which appears 44 times in the movie. Obscenity is found as the most effective one to get other's attention. Moreover, the characters do not merely use obscenity to show the literal meaning of doing sexual acts, but they use it as the expletive infixation in every time they speak to emphasize their statement. Meanwhile, the lowest amount of the types of taboo words uttered in the movie is vulgarity which appears only 20 times. This type of taboo word is found to be the least effectively used since only certain people from lower class are found in the movie use that.

Still, in relation to taboo words, there are four function of uttering taboo words which are to draw attention to one self, to be aggressive or to provocative, to show contempt, and to mock authority. The hugest amount of the function of taboo words found in the movie is to draw attention to one self that appears 114 times. To draw attention is concluded as the most effectively used by the characters since their intentions to use taboo words is to make other people or listeners can immediately pay attention to the speaker and catch what the speaker really means. The function of taboo words which is to mock authority gets the lowest frequency that only 5 times appears in the movie. Even though this movie shows some political issues and the country's problem in America, to draw attention does not become the most used one in the movie, but in other words it even becomes the least used among other functions of taboo words. It is because most of the scenes in the movie show the survival actions in the Purge night that are done by the characters rather than showing the real political issue itself.

Identifying as well as describing the types of euphemisms used in the movie that has been done in detail in finding and discussion is the second objective of this research. There are 112 words appear in the movie that are indicated as Euphemisms with the four types of it which are euphemisms for death and killing, euphemisms for political correctness, euphemisms for sexual activities, and euphemisms for addressing. euphemisms for death and killing are uttered the most that appear 105 times in the movie which is the greatest amount among other types. This is supported by the utterance of the word 'Purge' in most of every scene in the movie that makes the total amount of euphemisms for killing is exploding and can reach that number in total. Moreover, euphemisms for killing is concluded as the most effective way to be used in order to blur the literal meaning of killing itself that people are scared to hear. The opposite amount is covered from euphemisms for addressing which is the least uttered in the movie which only appears 1 time and makes it as the lowest frequency among other types. 


\section{REFERENCES}

Allan, K., \& Burridge, K. (2006). Forbidden words: Taboo and the censoring of language. New York: Cambridge University Press.

Anglick, S., Jazyka, H. O., \& Diplomov, D. (2019). Complex Words of the Type "Absobloominlutely." Unpublished master's thesis. Department of Language and Literature: Univerzita Karlova.

Battistella, E. L. (2005). Bad language: Are some words better than others? ew York: Oxford University Press, Inc.

Bengtsson, M. (2016). How to plan and perform a qualitative study using content analysis. NursingPlus Open, 2, 8-14.

Bowen, G. A. (2009). Document analysis as a qualitative research method. Qualitative Research Journal, 9(2), 27-40.

Brock, R. (Eds.). (2000). Death and disease in the ancient city. Death and disease in the ancient city. London and New York: Routledge.

Burridge, K. (2012). Euphemism and Language Change: The Sixth and Seventh Ages. Lexis, 7, 65-92.

Butter the bagel. Definithing. (2020). Retrieved July 26, 2020, from https://definithing.com/butterthe-bagel/

Candra, K. D. P., \& Megandari, N. P. C. (2018). The use of swear words and its relationship with taboo words in fist fight movie. Unpublished Thesis. Department of English Language and Literature: STIBA Saraswati Denpasar.

Cruse, A. (2006). A glossary of of semantics and pragmatics. Edinburgh: Edinburgh University Press.

Dalzell, T., \& Victor, T. (2006). The new partridge dictionary of slang and unconventional english. New York: Routledge.

Fadaee, E. (2011). Symbols, metaphors and similes in literature: A case study of "Animal Farm." Journal of English and Literature, 2(2), 19-27.

Farisi, M. S. Al, Adi, \& Astuti, E. S. (2017). A Sociolinguistic Analysis of Taboo Words in
Alpha Dog Movie. Journal of English Language and Pedagogy, 2, 1-18.

Fitzgerald, M. (2007). Offensive language spoken on popular morning radio programs. Unpublished Dissertation. Department of Communication: Florida State University Libraries.

Foolen, A. (2012). The relevance of emotion for language and linguistics. USA: John Benjamins Publishing Company.

Fradenburg, L. O., \& Freccero, C. (1995). The Pleasures of History. GLQ: A Journal of Lesbian and Gay Studies, 1(4), 371-384.

Fromkin, V., Rodman, R., \& Hyams, N. (2003). An introduction to language writing (9th ed). Canada: CENGANGE Learning.

Gao, C. (2013). A sociolinguistic study of english taboo language. Theory and Practice in Language Studies, 3(12), 2311.

Group, P. E. (n.d.). Contempt. Retrieved January 15, 2020, from https://google.com/amp/s/www.paulekman.co $\mathrm{m} /$ universal-emotions/what-is-contempt/amp/

Hafiza, M., \& Rosa, R. N. (2020). An analysis of word formation of english slang used in straight outta compton movie. E-Journal of English Language \& Literature ISSN, 9(1).

Hoeksema, J. (Ed.). (2019). The oxford handbook of taboo words and language. New York: Oxford University Press, Inc.

Holder, R. W. (2008). Dictionary of euphemisms. New York: OUP Oxford.

Holgate, E., Cachola, I., Preotiuc-Pietro, D., \& Li, J. J. (2020). Why swear? Analyzing and inferring the intentions of vulgar expressions. Proceedings of the 2018 Conference on Empirical Methods in Natural Language Processing, EMNLP 2018, 4405-4414.

Jay, T. (1992). Cursing in america. Amsterdam: John Benjamins Publishing Company.

Jay, T. (2009). The utility and ubiquity of taboo words. Perspectives on Psychological Science, 4(2), 153-161. 
Jay, T., \& Janschewitz, K. (2008). The pragmatics of swearing. Journal of Politeness Research, 4(2), 267-288.

Jdetawy, L. F. (2019). The nature, types, motives, and functions of swear words: A sociolinguistic analysis. International Journal of Development Research, 9(4), 27048-27058.

Kennedy, D. F., \& Lubiner, E. D. (1993). An introduction to sociolinguistics (4th ed). New York: Routledge.

Kreidler, C. W. (2013). In Introducing English Semantic(2nd ed). London and New York: Routledge.

Krizan, A. C. "Buddy," Merrier, P., Logan, J., \& Williams, K. (2008). Business communication (7th ed). USA: Thomson South-Western.

Kusumaningsih, D. G. Y. (2019). Taboo Words in 21 Jump Street Movie. RETORIKA: Jurnal Ilmu Bahasa, 5(1), 23-31.

McGuire, S. M. (1973). Obscenity: Its use and abuse. The Communicator, 4(2), 6-13.

Mercury, R.-E. (1995). Swearing: A "bad" part of language; A good part of language learning. TESL Canada Journal, 13(1), 28.

Miles, M. B., \& Huberman, A. M. (1984). Drawing valid meaning from qualitative data: Toward a shared craft. Educational Researcher, 13(5), 23-24.

Miller, P. R. (2015). Conspiracy Bullshit. Rhetoric Society Quarterly, 45(5), 464-467.

Mocanu, M. (2017). Taboo and Euphemism in the Religious Language. International Letters of Social and Humanistic Sciences, 75, 1-9.

Mózo, B. S. (2017). 21st century political euphemisms in english newspapers: Semantic and structural study. Journal of Chemical Information and Modeling, 53(9), 1689-1699.

Nordquist, R. (2019). What are utterances in english (speech)? . Retrieved September 05, 2020, from https://www/thoughtco.com/utterancespeech-1692576.

Rahmayani, D. P., \& Fitrawati. (2018). Analysis types and functions of taboo words in "the wolf of wall street" movie. E-Journal of English Language and Literature Volume, 7(336-345).

Rawson, H. (1981). Euphemisms \& other doubletalk. Canada: General Publishing Company.

Ruiz, R. S., \& Cirugeda, I. L. (2015). Persuasion and Manipulation Through Conceptual Metaphors in George Ridpath's Political Writings (1707-1709). US-China Foreign Language, 13(6), 397-411.

Telles, S., Reddy, S. K., \& Nagendra, H. R. (2019). An analysis of taboo words in rich brian's song lyrics. Journal of Chemical Information and Modeling, 53(9), 1689-1699.

Traum, D. R., \& Heeman, P. A. (1997). Utterance units in spoken dialogue. Lecture Notes in Computer Science (Including Subseries Lecture Notes in Artificial Intelligence and Lecture Notes in Bioinformatics), 1236, 125140.

Wachal, R. S. (2002). Taboo or not taboo: That is the question. American Speech, 77(2), 195206.

Wardaugh, R. (2006). An introduction to sociolinguistics. In The British Journal of Sociology (5th ed). UK: Blackwell Publishing Ltd.

Warren, B. (1992). What euphemisms tell us about the interpretation of words. Studia Linguistica, 46(2), 128-172.

The purge: election year. scripts.(2016). Retrieved June $\quad 30, \quad 2019, \quad$ from https://www.scripts.com/script/the_purge\%3A _election_year_21138. 